\title{
PENGARUH MUTAGEN ULTRAVIOLET DAN ETIL METAN SULFONAT TERHADAP KADAR PENISILIN G PADA Penicillium chrysogenum
}

\author{
(The Effect of Ultraviolet and Ethyl Methane Sulfonate Mutagens on Penicillin G level in \\ Penicillium chrysogenum)
}

\section{Eris Septiana, Martha Sari, Siti Irma Rahmawati, Fauzia Nurul Izzati, Rikno Harmoko, Apon Zaenal Mustopa}

Pusat Penelitian Bioteknologi LIPI, Jl. Raya Bogor KM 46, Cibinong, Bogor 16911, Indonesia

e-mail: septiana.eris@gmail.com

Diterima 16 Desember 2020, Revisi akhir 21 April 2021, Disetujui 28 Mei 2021

\begin{abstract}
ABSTRAK. Penicillium chrysogenum adalah salah satu kapang yang diketahui memproduksi antibiotik penisilin $G$. Strain P. chrysogenum unggul penghasil penisilin $G$ tinggi yang saat ini tersedia merupakan galur yang telah melalui berbagai tahapan pemuliaan dari wild type-nya. Isolat P. chrysogenum asal Indonesia juga memiliki potensi besar untuk dikembangkan. Oleh karena itu, penelitian ini bertujuan untuk mengetahui perubahan kadar penisilin $G$ dari isolat $P$. chrysogenum yang telah dimutasikan menggunakan radiasi sinar ultraviolet (UV) dan mutagen kimiawi etil metan sulfonat (EMS) dibandingkan dengan wild type nya. Mutasi acak menggunakan radiasi sinar UV, mutagen kimiawi EMS dan kombinasi keduanya dilakukan pada isolat P. chrysogenum. Uji aktivitas antibakteri dilakukan terhadap Escherichia coli dan Bacillus subtilis. Kadar penisilin G yang diproduksi dideteksi menggunakan HPLC dan dibandingkan dengan standar Penicillin G. Hasil penelitian menunjukkan bahwa mutasi menggunakan sinar UV, EMS dan kombinasi keduanya dapat meningkatkan aktivitas antibakteri serta kadar penisilin G dibandingkan dengan wild type nya. Isolat mutan C5-4.10 hasil mutasi kombinasi sinar UV dan EMS memiliki aktivitas antibakteri terbaik dan kadar penisilin $G$ sebesar 2,9 kali lipat dibandingkan dengan wild type nya.
\end{abstract}

Kata kunci: antibiotik, HPLC, mutasi, Penicillium chrysogenum, penisilin G

\begin{abstract}
Penicillium chrysogenum is one of the fungi which known to produce penicillin G antibiotics. The current superior strain P. chrysogenum producing high penicillin $G$ has gone through various stages from the wild type isolates. The wild type isolates of $P$. chrysogenum from Indonesia also have great potential to be developed. Therefore, this study aimed to determine the changes of penicillin G levels from mutated $P$. chrysogenum isolate with both ultraviolet $(U V)$ radiation and chemical mutagens ethyl methane sulfonate (EMS) compared to the wild type isolates. Random mutation through UV radiation, EMS chemical mutagen and their combination was carried out on wild type isolates of P. chrysogenum. Antibacterial activity was tested against Escherichia coli and Bacillus subtilis. The level of penicillin G produced was detected using HPLC with the Penicillin $G$ as the standard. The results showed that the treatment of $U V$, EMS mutations and their combination can increase the antibacterial activity as well as levels of penicillin $G$ than the wild type. Mutant C5-4.10 isolate resulted from the combination UV and EMS had the best antibacterial activity and produced penicillin G. level 2.9 times compared to the wild type.
\end{abstract}

Keywords: antibiotic, HPLC, mutation, Penicillium chrysogenum, penicillin $G$

\section{PENDAHULUAN}

Kapang merupakan salah satu mikroorganisme yang telah lama digunakan sebagai sumber senyawa bioaktif. Kapang penghasil senyawa bioaktif tersebut diisolasi mulai dari lautan (Wiese \& Imhoff, 2018) hingga daerah pegunungan
(Gerea et al., 2012). Salah satu senyawa bioaktif yang banyak diteliti dari kapang adalah antibiotik. Salah satu kapang yang merupakan pelopor pengembangan senyawa antibiotik adalah Penicillium. Penicillium chrysogenum digunakan secara luas di bidang industri farmasi sebagai 
penghasil antibiotik golongan beta-laktam seperti penisilin dan sefalosporin. Galur unggul yang digunakan saat ini merupakan hasil pengembangan strain konvensional yang menghasilkan peningkatan produktivitas yang sangat tinggi (Thykaer \& Nielsen, 2003).

Pemuliaan galur secara konvensional melalui mutasi acak dan skrining telah banyak digunakan untuk mendapatkan galur unggul. Salah satu cara yang digunakan ialah dengan mutasi fisik radiasi sinar ultraviolet (UV). Teknik radiasi sinar UV merupakan teknik yang sangat efektif untuk melakukan mutasi karena basa nitrogen DNA akan menyerap radiasi sinar UV. Akibat dari penyerapan ini akan menyebabkan terjadinya dimer timin dan silang tautan dalam untaian yang sama (Parekh et al., 2000). Selain mutasi secara fisik menggunakan radiasi sinar UV, mutasi secara kimia juga telah digunakan. Etil metan sulfonat (EMS) merupakan mutagen kimia yang sering digunakan untuk mutasi bahan hidup. Penelitian sebelumnya melaporkan bahwa EMS dan radiasi sinar UV dapat digunakan sebagai agen mutasi untuk meningkatkan produksi antibiotik yang dihasilkan oleh kapang (Veerapagu et al., 2008).

Antibiotik merupakan semua bahan yang berasal dari alam ataupun hasil sintetis dengan kemampuan toksisitas selektif terhadap satu atau beberapa mikroba target namun memiliki toksisitas rendah terhadap inangnya (Elander, 2003). Penisilin merupakan salah satu antibiotik yang secara luas digunakan untuk menanggulangi infeksi yang disebabkan oleh bakteri. Penisilin merupakan antibiotik golongan beta-laktam yang memiliki nilai ekonomi yang tinggi karena merupakan antibiotik paling umum digunakan begitu pula sintetis turunanya seperti amoksisilin dan ampisilin (Rachman et al., 2016). Mekanisme kerja penisilin yaitu menghambat sintesis dinding sel bakteri dengan cara berikatan dengan enzim transpeptidase yang terhubung dengan molekul peptidoglikan (Hardianto et al., 2015).

Indonesia memiliki kendala dalam penyediaan bahan baku obat antibiotik. Hal ini dapat diketahui karena $95 \%$ bahan baku obat antibiotik masih didatangkan dari negara lain (Wiharyanti et al., 2014), salah satunya adalah penisilin G. Penisilin G merupakan bahan baku bagi pembuatan antibiotik turunannya seperti amoksisilin dan ampisilin. Salah satu upaya untuk mulai menuju kemandirian bahan baku obat antibiotik ialah dengan mulai melakukan pemuliaan kapang penghasil penisilin $\mathrm{G}$ seperti $P$. chrysogenum. Di dalam sel kapang, biosintesis penisilin G melibatkan 3 gen utama yaitu $d(L-a-$ aminoadipyl)-L-cysteinyl-D-valine synthetase (acvA), isopenicillin $N$ synthase (ipnA) dan acyl coenzyme A: isopenicillin $N$ acyltransferase (aatA) (Ziemons et al., 2017). Mengingat keragaman mikroba Indonesia yang sangat melimpah, maka pencarian strain unggul isolat kapang penghasil penisilin $\mathrm{G}$ masih terus dilakukan. Oleh karena itu, penelitian ini bertujuan untuk mengetahui perubahan kadar penisilin $\mathrm{G}$ dari isolat kapang $P$. chrysogenum yang dimutasi dengan radiasi sinar UV dan mutagen kimia EMS dibandingkan dengan isolat wild type-nya.

\section{METODE PENELITIAN}

\section{Preparasi Suspensi Spora Uji}

Preparasi suspensi spora mengacu pada metode Syafriana et al. (2014). Kapang $P$. chrysogenum IPBCC 070555 (Gambar 1) ditumbuhkan dalam media Potato Dextrose Agar (PDA) agar miring selama 7 hari hingga bersporulasi. Sepuluh $\mathrm{mL}$ air distilasi steril yang mengandung tween-80 0,1\% dituangkan ke dalam tabung miring dan diambil menggunakan ose lalu dihomogenkan menggunakan vortex untuk mendapatkan suspensi spora. Suspensi spora kemudian diencerkan sampai pengenceran $10^{-3}$ dan disimpan dalam tabung mikro.

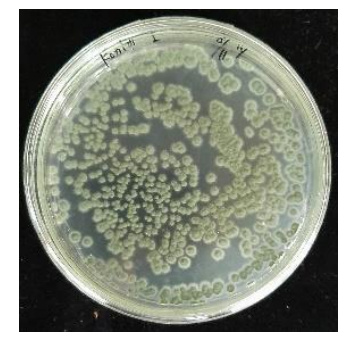

Gambar 1. Isolat Penicillium chrysogenum IPBCC 07 0555

\section{Mutasi Tunggal Menggunakan Mutagen Ultraviolet UV dan Etil Metan Sulfonat EMS}

Mutasi tunggal yang dilakukan pada penelitian ini berupa mutasi menggunakan mutagen UV dan EMS. Mutasi tunggal menggunakan mutagen UV mengacu pada metode Rajeshkumar \& Ilyas (2011) dan Radha et al. (2012) yang dimodifikasi. Sebanyak satu $\mathrm{mL}$ suspensi spora $\left(1,5 \times 10^{3} \mathrm{CFU} / \mathrm{mL}\right)$ dipipet dan diletakkan di dalam cawan petri kosong steril. Suspensi spora kemudian dipapar di bawah sinar UV mengunakan lampu UV$\mathrm{C}(\lambda 254 \mathrm{~nm})$ di dalam laminar air flow dengan jarak $15 \mathrm{~cm}$ dari lampu UV. Inkubasi dilakukan dengan variasi lama penyinaran yaitu $0,5,10,15$, 20 dan 25 menit. Suspensi spora yang telah di sinari 
UV kemudian dipindahkan ke dalam tabung mikro $1,5 \mathrm{~mL}$ yang kemudian disentrifugasi pada kecepatan putaran $13.000 \mathrm{rpm}$ selama 5 menit.

Mutasi menggunakan mutagen EMS mengacu pada metode Radha et al. (2012) yang dimodifikasi. Sebanyak satu $\mathrm{mL}$ suspensi spora $\left(1,5 \times 10^{3} \mathrm{CFU} / \mathrm{mL}\right)$ dipipet ke dalam tabung mikro yang masing-masing telah berisi larutan EMS dengan variasi konsentrasi sebesar 2, 4, 6, 8 dan 10 $\%$ (v/v). Suspensi spora dan larutan EMS kemudian dihomogenkan menggunakan vortex untuk selanjutnya diinkubasi di atas shaker dengan kecepatan $120 \mathrm{rpm}$ selama 60 menit pada suhu ruang. Setelah inkubasi, suspensi spora kemudian dicuci 3 kali dengan $500 \mu \mathrm{L}$ akuades steril dengan masing-masing pencucian disentrifugasi pada kecepatan putaran $13.000 \mathrm{rpm}$ selama 5 menit. Setelah sentrifugasi, supernatan dari hasil perlakuan UV maupun EMS dibuang dan sedimen spora dilarutkan dengan $200 \mu \mathrm{L}$ air fisiologis steril lalu dihomogenkan dengan vortex. Sebanyak $100 \mu \mathrm{L}$ suspensi spora kemudian disebar di permukaan media PDA steril dalam dua cawan petri untuk selanjutnya diinkubasi pada suhu $30{ }^{\circ} \mathrm{C}$ selama 5 hari. Jumlah koloni mutan yang tumbuh di dua cawan petri kemudian dihitung.

\section{Mutasi Kombinasi Menggunakan Mutagen UV dan EMS}

Mutasi kombinasi menggunakan mutagen UV dan EMS mengacu pada metode Syafriana et al. (2014) yang didasarkan pada konsentrasi dan lama waktu radiasi yang masih menunjukkan adanya pertumbuhan mutan. Sebanyak satu $\mathrm{mL}$ suspensi spora $\left(1,5 \times 10^{3} \mathrm{CFU} / \mathrm{mL}\right)$ dipipet dan diletakkan di dalam cawan petri kosong steril. Suspensi spora kemudian dipapar di bawah sinar UV mengunakan lampu UV-C $(\lambda 254 \mathrm{~nm})$ di dalam laminar air flow dengan jarak $15 \mathrm{~cm}$ dari lampu UV. Inkubasi dilakukan dengan variasi lama penyinaran yaitu 0 , 5, 10 dan 15 menit. Suspensi spora yang telah di sinari UV kemudian dipindahkan ke dalam masingmasing tabung mikro $1,5 \mathrm{~mL}$ yang telah berisi larutan EMS dengan variasi konsentrasi sebesar 2, 4 dan $6 \%$ (v/v). Suspensi spora dan larutan EMS kemudian dihomogenkan menggunakan vortex untuk selanjutnya diinkubasi menggunakan shaker dengan kecepatan 120 rpm selama 60 menit pada suhu ruang. Setelah inkubasi, suspensi spora kemudian dicuci 3 kali dengan $500 \mu \mathrm{L}$ akuades steril dengan masing-masing pencucian disentrifugasi pada kecepatan putaran $13.000 \mathrm{rpm}$ selama 5 menit. Setelah pencucian terahir, sedimen spora dilarutkan dengan $200 \mu \mathrm{L}$ air fisiologis steril kemudian dihomogenkan dengan vortex. Sebanyak $100 \mu \mathrm{L}$ suspensi spora kemudian disebar di permukaan media PDA steril dalam dua cawan petri untuk selanjutnya diinkubasi pada suhu $30{ }^{\circ} \mathrm{C}$ selama 5 hari. Jumlah koloni mutan yang tumbuh di dua cawan petri kemudian dihitung.

\section{Uji Antibakteri}

Sebanyak $100 \mu \mathrm{L}$ biakan $P$. chrysogenum mutan ditanam ke dalam $100 \mathrm{~mL}$ media steril Potato Dextrose Broth (PDB) dan difermentasi selama 10 hari pada suhu ruang menggunakan shaker $200 \mathrm{rpm}$ dengan penambahan 2\% larutan prekursor phenylacetic acid (PAA) $(0,58 \mathrm{mg} / \mathrm{L})$ (Harris et al., 2009) pada hari ketiga. Uji antimikroba metode cakram kertas Kirby-Bauer mengacu pada CLSI (2012). Sebanyak satu ose biakan bakteri uji ( $B$. subtilis dan $E$. coli) diambil dan dipindahkan ke dalam $5 \mathrm{~mL}$ media Nutrient Broth (NB) steril, diinkubasi menggunakan shaker $120 \mathrm{rpm}$ pada suhu $37{ }^{\circ} \mathrm{C}$ selama 24 jam. Suspensi bakteri uji umur 24 jam dipindahkan ke dalam media NB steril baru dan diukur kekeruhannya sampai setara dengan standar 0,5 McFarland (setara $1,5 \times 10^{8} \mathrm{CFU} / \mathrm{mL}$ ). Sebanyak $1 \mathrm{~mL}$ suspensi bakteri uji dicampurkan dengan $20 \mathrm{~mL}$ larutan media Mueller Hinton Agar (MHA) steril dalam cawan petri dan dihomogenkan dan didiamkan hingga membeku. Setelah agar membeku (sekitar 60 menit setelah penuangan), cakram kertas steril dengan diameter $6 \mathrm{~mm}$ diletakkan di pemukaan media agar dan ditambahkan $10 \mu \mathrm{L}$ hasil fermentasi cair dan kontrol positif penisilin G $1000 \mu \mathrm{g} / \mathrm{mL}$, masing-masing perlakuan dilakukan dua kali ulangan. Cawan petri kemudian diinkubasi pada suhu $37{ }^{\circ} \mathrm{C}$ selama 24 jam. Zona bening yang terbentuk kemudian diukur sebagai aktivitas antibakteri. Data yang ditampilkan pada tabel hanya yang mempunyai aktivitas penghambatan terhadap bakteri uji.

\section{Analisis Penisilin G}

Hasil fermentasi cair dengan kondisi yang sama dengan uji antibakteri disentrifugasi pada $30.000 \mathrm{rpm}$ selama 2 menit, supernatan disaring dengan filter $0,20 \mu \mathrm{m}$. Sebanyak $10 \mu \mathrm{L}$ hasil filtrasi diinjeksikan ke dalam HPLC Shimadzu berdasarkan pada metode dari Lieberman (2018) dengan sedikit modifikasi pada fase gerak yang digunakan. Kondisi HPLC yang digunakan meliputi kolom $\mathrm{C} 18$, suhu oven $27^{\circ} \mathrm{C}$, laju alir $1 \mathrm{~mL} / \mathrm{menit}$, volume injeksi $10 \mu \mathrm{L}$, fase gerak isokratik dapar fosfat 10 $\mathrm{mM}$ dengan metanol (2:8) serta menggunakan detektor UV pada $\lambda 220 \mathrm{~nm}$. Standar penisilin G 
digunakan sebagai pembanding untuk mengukur kadar penisilin $\mathrm{G}$ dalam sampel.

\section{HASIL DAN PEMBAHASAN}

\section{Mutasi Tunggal Menggunakan Mutagen UV dan EMS}

Mutasi merupakan salah satu cara untuk pemuliaan galur untuk mendapatkan isolat unggul yang diinginkan (Veerapagu et al., 2008). Proses pemuliaan secara konvensional ini mengakibatkan isolat kapang akan mengalami mutasi acak pada susunan basa nitrogennya. Kapang yang digunakan dalam penelitian ini ialah $P$. chrysogenum isolat IPBCC 07 0555. Hasil mutasi menggunakan sinar UV-C ( $\lambda 254 \mathrm{~nm}$ ), EMS dan kombinasi keduanya menghasilkan jumah total koloni mutan yang tumbuh pada setiap perlakuan seperti yang tersaji pada Tabel 1 dan 2. Total koloni mutan UV adalah sebanyak 71 isolat, mutan EMS sebanyak 18 isolat. Pada Tabel 1 dan 2 juga terlihat bahwa semakin lama waktu penyinaran UV dan semakin tinggi konsentrasi EMS, maka tingkat kematian (killing rate) kapang akan semakin tinggi.

Tabel 1. Kelangsungan hidup spora $P$. chrysogenum IPBCC 070555 setelah perlakuan radiasi tunggal UV

\begin{tabular}{ccc}
\hline Perlakuan (menit) & Jumlah koloni & Tingkat kematian (\%) \\
\hline 0 & 300 & 0 \\
5 & 55 & 81,7 \\
10 & 12 & 96 \\
15 & 4 & 98,7 \\
20 & 0 & 100 \\
25 & 0 & 100 \\
\hline
\end{tabular}

Hasil pengamatan koloni mutan terlihat bahwa semakin lama penyinaran dengan sinar UV dan semakin tinggi konsentrasi EMS maka semakin sedikit koloni mutan yang masih mampu hidup. Pada lama penyinaran selama 20 dan 25 menit serta konsentrasi EMS 8 dan 10\% sudah tidak didapatkan koloni mutan yang mampu tumbuh sehingga pada lama penyinaran dan konsentrasi tersebut killing rate nya mencapai $100 \%$. Mutagen radiasi sinar UV merupakan mutagen yang telah lama digunakan untuk perbaikan strain $P$. chrysogenum guna meningkatkan produksi penisilin G. Efek paparan sinar UV pada sel adalah perubahan basa pirimidin yang berdekatan pada untaian yang sama membentuk dimer yang disebut dimer pirimidin. Kehadiran dimer pirimidin mengakibatkan kerusakan struktur untai ganda DNA sehingga menghambat proses replikasi selanjutnya (Rochette et al., 2009). Selain UV, mutagen lainnya yang secara umum digunakan ialah mutagen kimia menggunakan senyawa EMS. Pengaruh paparan mutagen EMS terhadap sel adalah adanya alkilasi basa guanin dan menyebabkan pasangan $\mathrm{G}$ yang teralkilasi dengan $\mathrm{T}$ dibanding dengan $\mathrm{C}$. Hal ini akan mengakibatkan kesalahan pasang basa yang seharusnya G/C menjadi A/T (Mohd-Yusoff et al., 2015).

Tabel 2. Kelangsungan hidup spora $P$. chrysogenum IPBCC 070555 setelah perlakuan radiasi tunggal EMS

\begin{tabular}{ccc}
\hline Perlakuan (\%) & Jumlah koloni & Tingkat kematian $(\%)$ \\
\hline 0 & 240 & 0 \\
2 & 13 & 94,6 \\
4 & 3 & 98,8 \\
6 & 2 & 99,2 \\
8 & 0 & 100 \\
10 & 0 & 100 \\
\hline
\end{tabular}




\section{Mutasi Kombinasi Menggunakan Mutagen UV dan EMS}

Killing rate pada mutasi fisik dan kimia dijadikan sebagai acuan untuk menentukan kombinasi perlakuan pada isolasi mutan kombinasi. Pada mutasi UV didapatkan bahwa pada lama penyinaran 15 menit masih dijumpai pertumbuhan koloni mutan, begitu pula perlakuan menggunakan mutagen EMS pada konsentrasi 6\%. Kondisi itulah yang dijadikan sebagai dasar penentuan kombinasi perlakuan dua mutagen. Hasil mutasi menggunakan mutagen fisik dan kimia yaitu kombinasi UV dan EMS didapatkan 9 kombinasi mutagen serta menghasilkan beberapa koloni mutan seperti yang tersaji pada Tabel 3 .
Total koloni mutan kombinasi adalah sebanyak 29 isolat. Hasil pengamatan koloni mutan terlihat bahwa semakin tinggi konsentrasi mutagen EMS dan juga lama penyinaran UV maka semakin sedikit koloni mutan yang masih mampu hidup. Pada kombinasi mutagen (UV - EMS) 10-6, 15-2, 15-4, dan 15-6 sudah tidak didapatkan koloni mutan yang mampu tumbuh sehingga kombinasi tersebut killing rate nya mencapai $100 \%$. Kombinasi mutasi dengan dua mutagen yang berbeda akan meningkatkan aktivitas biologis strain kapang yang diinginkan dibandingkan dengan hanya menggunakan satu mutagen saja (Veerapagu et al., 2008).

Tabel 3. Kelangsungan hidup spora $P$. chrysogenum IPBCC 070555 setelah perlakuan radiasi kombinasi UV dan EMS

\begin{tabular}{ccc}
\hline Perlakuan (menit - \%) & Jumlah koloni & Tingkat kematian $(\%)$ \\
\hline $0-0$ & 210 & 0 \\
$5-2$ & 8 & 96,2 \\
$5-4$ & 16 & 93,4 \\
$5-6$ & 1 & 99,6 \\
$10-2$ & 1 & 99,6 \\
$10-4$ & 3 & 98,3 \\
$10-6$ & 0 & 100 \\
$15-2$ & 0 & 100 \\
$15-4$ & 0 & 100 \\
$15-6$ & 0 & 100 \\
\hline
\end{tabular}

\section{Uji Antibakteri}

Uji aktivitas antibakteri dilakukan untuk skrining awal sebelum analisis kadar penisilin $G$ dengan HPLC. Penisilin G memiliki aktivitas antibakteri sehingga diharapkan isolat yang memiliki aktivitas antibakteri akan terdeteksi kadar penisilin G saat dianalisis dengan HPLC. Bakteri uji yang digunakan dalam penelitian ini ialah dari golongan Gram positif yaitu B. subtilis dan dari golongan Gram negatif yaitu E. coli. Kedua bakteri tersebut merupakan bakteri model yang secara umum digunakan untuk mewakili golongan Gram negatif dan positif pada pengujian antibakteri (Leimbach et al., 2013; Zhu et al., 2017). Hasil uji aktivitas antibakteri isolat mutan UV dapat dilihat pada Gambar 2 dan Tabel 4. Data aktivitas antibakteri yang ditampilkan pada Tabel 4 hanya yang mempunyai aktivitas penghambatan terhadap bakteri uji. Jumlah isolat mutan yang diuji aktivitas
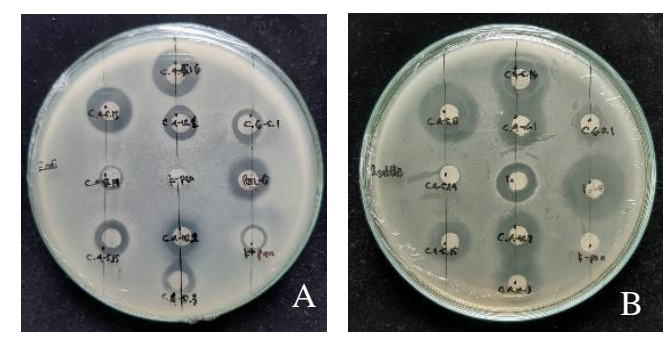

Gambar 2. Uji aktivitas antimikroba terhadap bakteri uji Escherichia coli (A) dan Bacillus subtilis (B)

antimikroba adalah 71 isolat, yaitu 54 isolat tidak memiliki aktivitas penghambatan pertumbuhan bakteri uji (data tidak ditampilkan) dan 17 isolat memiliki aktivitas antibakteri uji. Penghambatan pertumbuhan bakteri uji dari 17 isolat memiliki rentang diameter daya hambat berkisar antara 6-19 mm terhadap bakteri $E$. coli dan 6-17 mm terhadap 
bakteri B. subtilis. Isolat C5-4.10 (isolat nomor 10 hasil mutasi kombinasi lama penyinaran UV-C 5 menit dan 4\% EMS) memiliki aktivitas penghambatan tertinggi terhadap bakteri uji E. coli dan $B$. subtilis dengan diameter daya hambat masing-masing sebesar 19 dan $17 \mathrm{~mm}$.

Penisilin $\mathrm{G}$ adalah golongan penisilin alami pertama yang digunakan sebagai antibiotik. Penisilin memiliki aktivitas antibakteri dengan cara menghambat sintesis peptidoglikan yang membangun dinding sel bakteri. Penisilin lebih aktif dalam menghambat bakteri Gram positif dibandingkan dengan Gram negatif karena dinding sel bakteri Gram positif tersusun atas lapisan peptidoglikan. Penisilin akan bertindak menyerupai substrat dari enzim transpeptidase pada fase akhir pembentukan dinding sel peptidoglikan. Oleh karena itu, sintesis dinding sel baru akan terhenti dan menyebabkan kematian sel (Soares et al., 2012).

Tabel 4. Aktivitas antibakteri isolat mutan tunggal dan kombinasi P. chrysogenum IPBCC 070555

\begin{tabular}{cccc}
\hline \multirow{2}{*}{ Perlakuan } & Kode mutan & \multicolumn{2}{c}{ Diameter daya hambat (mm) } \\
\cline { 3 - 4 } Wild type & Wt & Escherichia coli & Bacillus subtilis \\
\hline & & $6 \pm 0,28$ & $6 \pm 0,34$ \\
UV & UV5-2 & $6 \pm 0,23$ & $6 \pm 0,03$ \\
& UV10-4 & $7 \pm 0,57$ & $6 \pm 0,06$ \\
UV10-10 & $7,5 \pm 0,20$ & $6 \pm 0,14$ \\
UV15-2 & $6,5 \pm 0,11$ & $6 \pm 0,17$ \\
EMS & & & $6 \pm 0,25$ \\
& EMS2-5 & $7 \pm 0,08$ & $6 \pm 0,11$ \\
& EMS2-6 & $8 \pm 0,25$ & $6 \pm 0,2$ \\
& EMS4-2 & $6,5 \pm 0,14$ & $7 \pm 0,28$ \\
& EMS4-3 & $9 \pm 0,31$ & $6 \pm 0,23$ \\
EMS6-2 & $6 \pm 0,34$ & $8 \pm 0,37$ \\
& & & $9,5 \pm 0,48$ \\
& C5-2.4 & $7 \pm 0,37$ & $9 \pm 0,31$ \\
& C5-2.8 & $9 \pm 0,40$ & $16 \pm 0,99$ \\
& C10-2.1 & $14 \pm 0,42$ & $17 \pm 0,65$ \\
& C5-4.10 & $18 \pm 0,45$ & $14 \pm 0,76$ \\
& C10-4.1 & $19 \pm 0,65$ & $13 \pm 0,71$ \\
& C10-4.3 & $10 \pm 0,48$ & $8 \pm 0,34$ \\
& & $10 \pm 0,51$ & $26,5 \pm 0,06$ \\
\hline
\end{tabular}

Keterangan kode mutan: $\mathrm{Wt}$ menunjukkan wild type; kelompok mutagen UV menunjukkan lama menit penyinaran UV-nomor isolat; kelompok mutagen EMS menunjukan persentase konsentrasi EMS-nomor isolat; mutagen kombinasi UV-EMS menunjukkan kombinasi lama menit penyinaran UV-persentase konsentrasi EMS.nomor isolat).

Pada dasarnya, penisilin G hanya aktif melawan bakteri Gram positif dan memiliki efek yang lebih kecil pada bakteri Gram negatif. Bakteri Gram negatif seperti E. coli memiliki lapisan membran luar yang terdiri dari lapisan lipid yang unik berupa lipopolisakarida. Lapisan membran luar lipopolisakarida ini bersifat hidrofilik. Lapisan hidrofilik ini akan melindungi sel dari antibiotik hidrofobik seperti penisilin G. Selain itu, membran luar ini akan menyeleksi ukuran partikel yang dapat melewatinya, dimana penisilin $G$ memiliki berat molekul yang relatif besar, sehingga secara fisik tidak dapat melewati bagian luar lapisan membran ini (Lehtinen \& Lilius, 2007). Namun, pada penelitian ini ekstrak yang mengandung senyawa metabolit sekunder dari $P$. chrysogenum dapat menghambat pertumbuhan bakteri Gram negatif $E$. coli bahkan yang berasal dari mutan kombinasi memiliki daya hambat yang lebih besar dibandingkan penisilin $\mathrm{G}$ sebagai kontrol positif. Perbedaan aktivitas antibakteri dari ekstrak isolat mutan terhadap bakteri uji dapat terjadi karena ekstrak yang digunakan belum melalui proses pemurnian sehingga senyawa antibiotik yang terkandung di dalamnya dimungkinkan tidak hanya Penisilin $\mathrm{G}$ namun ada beberapa senyawa lain yang dapat merusak dinding sel $E$. coli.

Secara umum aktivitas antibakteri meningkat pada isolat mutan dibandingkan dengan wild typenya. Selain itu, mutan EMS memberikan 
peningkatan aktivitas antibakteri yang lebih tinggi dibandingkan dengan mutan UV. Kombinasi mutan UV-EMS memberikan kenaikan aktivitas antibakteri yang paling signifikan dibandingkan mutan UV dan EMS. Respon isolat mutan kapang Penicillium terhadap mutagen UV dan EMS ataupun kombinasinya akan berbeda bergantung kepada senyawa apa yang ingin dihasilkan. Syafriana et al. (2014) melaporkan bahwa kombinasi mutasi UV dan EMS tidak efektif dalam meningkatkan aktivitas $\beta$-glukosidse pada isolat Penicillium sp. dibandingkan dengan mutasi UV atau EMS saja.

\section{Analisis Penisilin G}

Telah dipilih masing-masing satu isolat mutan dengan aktivitas antibakteri terbaik dari setiap perlakuan ditambah wild type sehingga ada 4 isolat yang dilakukan analisis kadar penisilin G. Kultur yang digunakan merupakan hasil fermentasi dengan kondisi yang sama untuk uji antibakteri yaitu hasil fermentasi pada media PDB selama 10 hari pada suhu ruang menggunakan shaker $200 \mathrm{rpm}$ dengan penambahan 2\% larutan prekursor phenylacetic acid (PAA) $(0,58 \mathrm{mg} / \mathrm{L})$. Kondisi kadar penisilin $\mathrm{G}$ dari isolat mutan terpilih dapat dilihat pada Gambar 3. Hasil analisis menggunakan HPLC menunjukkan bahwa waktu retensi (Retention Time/RT) penisilin G dengan kondisi HPLC yang disebutkan pada metode ialah sekitar menit ke 2,7. Waktu retensi penisilin G yang terdeteksi dari sampel media fermentasi isolat kapang wild type maupun mutan berkisar antara menit 2,7 - 2,8. Kadar penisilin G pada sampel isolat mutan berkisar antara 185,96-502,07 mg/L, sedangkan pada isolat wild type kadar penisilin $\mathrm{G}$ sebesar 171,69 mg/L. Kadar penisilin G tertinggi dihasilkan oleh $P$. chrysogenum IPBCC 070555 isolat mutan $\mathrm{C} 5-4.10$ yang merupakan isolat nomor 10 hasil mutasi kombinasi lama penyinaran UV-C selama 5 menit dan 4\% EMS. Kadar penisilin G yang dihasilkan oleh isolat asal $P$. chrysogenum pada penelitian ini masih lebih rendah dibandingkan dengan isolat yang telah dilaporkan sebelumnya oleh Hardianto et al. (2015) yaitu sebesar 3711 $\mathrm{mg} / \mathrm{L}$. Akan tetapi, peningkatan kadar penisilin G isolat mutan pada penelitian ini lebih tinggi yaitu sebesar 2,9 kali dari isolat asalnya dibandingkan dengan hasil penelitian sebelumnya yang hanya mengalami peningkatan sebesar 1,23 kali dengan menggunakan UV sebagai agen mutasinya. Isolat mutan terpilih memiliki kadar penisilin $G$ yang lebih tinggi dibandingkan dengan isolat wild typenya. Hal ini sejalan dengan penelitian sebelumnya yang melaporkan bahwa $P$. chrysogenum yang diradiasi dengan sinar UV atau EMS menunjukkan peningkatan produksi penisilin $\mathrm{G}$ dibandingkan dengan isolat wild type-nya (Onyegeme-Okerenta et al., 2013; Veerapagu et al., 2008).

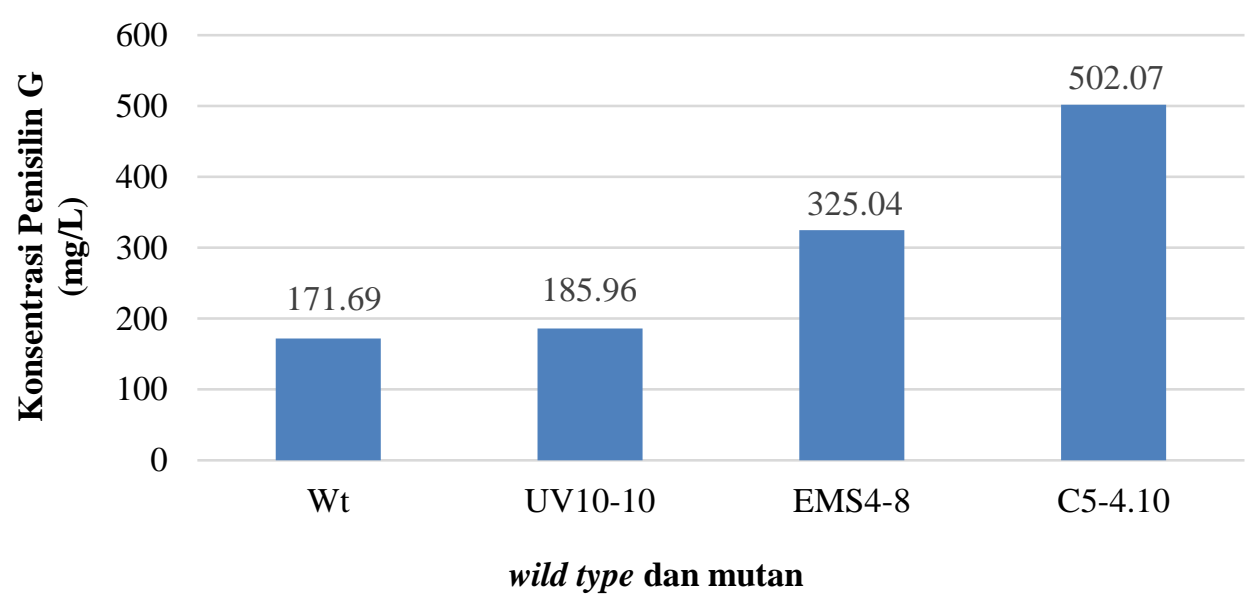

Gambar 3. Kadar penisilin G pada isolat wild type dan mutan P. Chrysogenum

Penambahan PAA pada media fermentasi dimaksudkan sebagai prekursor pembentukan penisilin G. Penambahan PAA pada media fermentasi akan memicu pembentukan penisilin $\mathrm{G}$ (Pramisandi et al., 2012). PAA dalam dosis tinggi akan menghambat pertumbuhan $P$. chrysogenum karena sangat toksik terhadap hifa dan dapat menghambat pembentukan penisilin G (Brakhage, 1998). Oleh karena itu dalam penelitian ini, penggunaan PAA hanya pada dosis rendah. Penambahan PAA juga belum dilakukan pada hari pertama fermentasi. Hal ini karena PAA bersifat asam dan dapat menghambat pertumbuhan $P$. chrysogenum (White et al., 1999). 
Penggunaan kombinasi mutagen UV dan EMS pada penelitian ini dapat meningkatkan kadar penisilin $\mathrm{G}$ yang dihasilkan oleh mutan $P$. chrysogenum. Kadar penisilin $G$ yang diukur dengan instrumen HPLC berbanding lurus dengan aktivitas antibakterinya. Semakin besar diameter aktivitas penghambatan pada uji antimikroba maka semakin tinggi kadar penisilin G. Hasil ini juga sejalan dengan penelitian sebelumnya yang melaporkan bahwa $P$. chrysogenum PCL501 yang selama ini diketahui memproduksi antibiotik betalaktam juga memiliki aktivitas antibakteri terhadap Gram negatif E. coli dan Gram positif B. subtilis (Onyegeme-Okerenta et al., 2009).

\section{KESIMPULAN}

Perlakuan mutasi menggunakan mutagen sinar UV dan EMS serta kombinasinya dapat meningkatkan aktivitas antibakteri dan juga kadar penisilin $\mathrm{G}$ dari kapang $P$. chrysogenum IPBCC 07 0555. Isolat $P$. chrysogenum mutan C5-4.10 hasil dari mutasi kombinasi menggunakan mutagen sinar UV dan EMS memiliki aktivitas antibakteri dan kadar penisilin $\mathrm{G}$ sebesar 2,9 kali lipat dibandingkan dengan wild type nya.

\section{UCAPAN TERIMA KASIH}

Penulis mengucapkan terima kasih kepada Lembaga Ilmu Pengetahuan Indonesia atas pendanaan penelitian ini melalui dana DIPA 2019 dan IPBCC atas penyediaan isolat Penicillium chrysogenum.

\section{DAFTAR PUSTAKA}

Brakhage, A. A. (1998). Molecular regulation of $\beta$ lactam biosynthesis in filamentous fungi. Microbiology and Molecular Biology Reviews, 62, 547-585.

CLSI. (2012). Performance Standards for Antimicrobial Disk Susceptibility Tests. 11st Ed. CLSI standard M02. Pennsylvania: Clinical and Laboratory Standards Institute.

Elander, R. P. (2003). Industrial production $\beta$-lactam antibiotics. Applied Microbiology and Biotechnology, 61, 385-392.

Gerea, A. L., Branscum, K. M., King, J. B., You, J., Powell, D. R., Miller, A. N., Spear, J. R., \& Cichewicz, R. H. (2012). Secondary metabolites produced by fungi derived from a microbial mat encountered in an iron-rich natural spring. Tetrahedron Letters, 53, 4202-4205.

Hardianto, D., Suyanto, Prabandari, E. E., Windriawati. L., Marwanta, E., \& Tarwadi. (2015). Penicillin production by mutant of Penicillium chrysogenum. Jurnal Bioteknologi \& Biosains Indonesia, 2, 61-65.

Harris, D. M., Van der Kroght, Z. A., Klaassen, P., Raamsdonk, L. M., Hage, S., Van den Berg, M., Bovenberg, R. A. L., Pronk, J. T., \& Daran, J-M. (2009). Exploring and dissecting genome-wide gene expression responses of Penicillium chrysogenum to phenylacetic acid consumption and penicillin $\mathrm{G}$ production. BMC Genomics, 10, 75.

Lehtinen, J., \& Lilius, E. M. (2007). Promethazine renders Eschrichia coli susceptible to penicillin G: real-time measurement of bacterial susceptibility by fluoro-luminometry. International Journal of Antimicrobial Agents, 30, 44-51.

Leimbach, A., Hacker, j., \& Dobrindt, U. (2013). E. coli as an all-rounder: the thin line between commensalism and pathogenicity. Current Topics in Microbiology and Immunology, 358, 3-52.

Lieberman, M. (2018). HPLC methodology manual: Distributed pharmaceutical analysis laboratory. Indiana: Department of chemistry and biochemistry, University of Notre Dame.

Mohd-Yusoff, N. F., Ruperao, P., Tomoyoshi, N. E., Edwards, D., Gresshoff, P. M., Biswas, B., \& Batley, J. (2015). Scanning the effects of ethyl methanesulfonate on the whole genome of Lotus japonicus using second-generation sequencing analysis. G3 (Bethesda), 5, 559-567.

Onyegeme-Okerenta, B. M., Chinedu, S. N., Okafor, U. A., \& Okochi, V. I. (2009). Antibacterial activity of culture extracts of Penicillium chrysogenum PCL501: effects of carbon sources. Online Journal of Health Allied Sciences, 8, 1-9.

Onyegeme-Okerenta, B. M., Okochi, V. I., \& Chinedu, S. N. (2013). Penicillin production by Penicillium chrysogenum PCL 501: effect of UV induced mutation. Internet Journal of Microbiology, 12, 17.

Parekh, S., Vinci, V. A., \& Strobel, R. J. (2000). Improvement of microbial strain and fermentation processes. Applied Microbiology and Biotechnology, 54, 287-301.

Pramisandi, A., Sunaryanto, R., Suyanto, \& Prabandari, E. E. (2012). Effect of phenylacetic acid addition on productivity of Penicillium chrysogenum in penicillin $\mathrm{G}$ production using pilot scale reactor. In Widayat, L. Buchori, N. A. Handayani (Eds.), $1^{\text {st }}$ International Conference on Chemical and Material Engineering (pp. BRE.15 1-6). Semarang: Diponegoro University. 
Rachman, S. D., Safari, A., Fazli, Kamara, D. S., Sidik, A., Udin, L. Z., \& Ishmayana, S. (2016). Produksi penisilin oleh Penicillium chrysogenum L112 dengan variasi kecepatan agitasi pada fermentor 1L. Kartika-Jurnal Ilmiah Farmasi, 4, 1-6.

Radha, S., Babul, R. H., Sridevi, A., Prasad, N. B. L., \& Narashima, G. (2012). Development of mutant fungal strain of Aspergillus niger for enhanced production of acid protease in submerged and solid state fermentation. European Journal of Experimental Biology, 2, 1517-1528.

Rajeshkumar, J., Ilyas, M. H. M. (2011). Production of phosphatase by mutated fungal strains. International Multidisiplinary Research Journal, 1, 23-29.

Rochette, P. J., Lacoste, S., Therrien, J. P., Bastien, N., Brash, D. E., \& Drouin, R. (2009). Influence of cytosine methylation on ultraviolet-induced cyclobutane pyrimidine dimer formation in genomic DNA. Mutation Research, 665, 7-13.

Soares, G. M. S., Figueiredo, L. C., Faveri, M., Cortelli, S. C., Duarte, P. M., \& Feres, M. (2012). Mechanisms of action of systemic antibiotics used in periodontal treatment and mechanisms of bacterial resistance to these drugs. Journal of Applied Oral Science, 20, 295-309.

Syafriana, V., Nuswantara, S., Mangunwardoyo, W., \& Lisdiyanti, P. (2014). Enhancement of $\beta$ glucosidase activity in Penicillium sp. by random mutation with ultraviolet and ethyl methyl sulfonate. Annales Bogorienses, 18, 27-33.
Thykaer, J., \& Nielsen, J. (2003). Metabolic engineering of beta-lactam production. Metabolic Engineering, 5, 56-69.

Veerapagu, M., Jeya, K. R., \& Ponmurugan, K. (2008). Mutational effect of Penicillium chrysogenum on antibiotic production. Short communication. Advanced BioTechnology, 8, 16-19.

White, S., Berry, D. R., \& McNeil, B. (1999). Effect of phenylacetic acid feeding on the process of cellular autolysis in submerged batch cultures of Penicillium chrysogenum. Journal of Biotechnology, 75, 173-185.

Wiese, J., \& Imhoff, J. F. (2018). Marine bacteria and fungi as promising source for new antibiotics. Drug Development Research, 80, 24-27.

Wiharyanti, R., Hardianto, D., Kusumaningrum, H. P., \& Budiharjo, A. (2014). Kloning gen $p c b C$ dari Penicillium chrysogenum ke dalam plasmid pPICZA untuk pengembangan produksi penisilin G. BIOMA, 16, 33-38.

Zhu, T. F., Chen, F. F., \& Li, J. C. (2017). A strain of pathogenic Bacillus subtilis results in brain damage in ducklings when co-infected with Riemerella anatipestifer. Polish Journal of Veterinary Sciences, 20, 803-809.

Ziemons, S., Koutsantas, K., Becker, K., Dahlmann, T., \& Kuck, U. (2017). Penicillin production in industrial strain Penicillium chrysogenum P2niaD18 is not dependent on the copy number of biosynthesis genes. BMC Biotechnology, 17, 16. 